\title{
ANALISIS INSTRUMEN MITIGASI KEBISINGAN LALU LINTAS PADA RUANG TERBUKA BINAAN PUBLIK (RTBPU) DI WILAYAH PERKOTAAN
}

\author{
Suhartina ${ }^{1}$, Faris Jumawan ${ }^{2}$, Meldawati Artayani3 ${ }^{3 *}$ \\ Program Studi Arsitektur, Universitas Fajar ${ }^{1}$, \\ Program Studi Arsitektur, Universitas Fajar², \\ Program Studi Arsitektur, Universitas Fajar ${ }^{3}$, \\ e-mail: ${ }^{1}$ ninabasrah@ymail.com, 2jfaris46@gmail.com, ${ }^{* 3}$ imelarta@gmail.com
}

\begin{abstract}
Abstrak_Pelataran pantai losari dalam perkembangannya sebagai ruang terbuka binaan publik (RTBPU) dirancang untuk memberikan kenyamanan bagi pengunjungnya, namun salah satu faktor penyebab munculnya ketidak nyamanan pengunjung adalah kebisingan. Berdasarkan hal tersebut, maka dipandang perlu untuk melakukan perhitungan tingkat kebisingan jalan raya pada Pelataran Pantai Losari guna mengetahui apakah tingkat kebisingan yang terjadi masih dapat ditolerir atau sudah melampaui ambang batas sehingga perlu dilakukan mitigasi untuk menurunkan tingkat kebisingan. Tujuan dari penelitian ini yaitu (1) mengidentifikasi tingkat kebisingan yang disebabkan oleh lalu lintas pada RTBP Pelataran Pantai Losari, (2) Menganalisis pengaruh instrument mitigasi kebisingan lalu lintas terhadap tingkat kenyamanan pengunjung pada RTBPU Pelataran Pantai Losari. Lokasi pengambilan data penelitian dilaksanakan di Pelataran Pantai Losari jalan Penghibur Kota Makassar, penelitian dilaksanakan pada 5 titik pengukuran selama 3 minggu, waktu pengukuran: pukul $07.00 \mathrm{~s} / \mathrm{d}$ 24.00 WITA. Jenis penelitian menggunakan survey bersifat analitik dengan metode cross sectional. Penelitian kebisingan Pelataran Pantai Losari menunjukkan bahwa rata-rata tingkat kebisingan dari aktivitas lalu lintas pada siang-malam hari sebesar 68,01 - 74,97 dB (A), dan tingkat kebisingan campuran dari aktivitas dari pengunjung dan aktivitas lalu lintas sebesar 68,02 - 73,86 dB (A). Instrument mitigasi yang berfungsi dengan baik dalam mereduksi kebisingan lalu lintas berada pada kawasan Pelataran bahari/pantai losari, hal ini dipengaruhi oleh banyaknya jenis dan jumlah instrument mitigasi yang terdapat pada daerah ukur seperti pohon, taman, tugu, sculpture/patung, disertai dengan jarak ukur yang besar.
\end{abstract}

Kata kunci: Mitigasi Kebisingan; Lalu Lintas; Pelataran Pantai Losari.

\begin{abstract}
The Yard of Losari Beach in its development as a public of open space built (RTBPU) is designed to provide comfort for its visitors, but one of the factors causing visitor inconvenience is noise. Based on this, it is necessary to calculate the road noise level at the Losari Beach Yard in order to determine whether the noise level that occurs can still be tolerated or has exceeded the threshold so that mitigation is needed to reduce the noise level. The objectives of this study were (1) Identifying the noise level caused by traffic at the RTBP Losari Beach Yard, (2) Analyzing the effect of traffic noise mitigation instruments on the comfort level of visitors at RTBPU Losari Beach Yard. The location of the data collection was carried out at the Losari Beach Yard on the Penghibur street in Makassar City, the study was conducted in 5 measurement points for 3 weeks, measurement time: 07.00 - 24.00 WITA. The type of research that used was an analytical survey with a cross sectional method. Noise research of Losari Beach Court showed that the average noise level of day-night traffic activity is $68.01-74.97 \mathrm{~dB}(A)$, and the mixed noise level of visitor activity and traffic activity is $68.02-73,86 \mathrm{~dB}(\mathrm{~A})$. Mitigation instruments that are function well in reducing traffic noise are in the maritime / beach area of Losari, this is influenced by the number and type of mitigation instruments found in measuring areas such as trees, parks, monuments, sculptures, accompanied by large distances
\end{abstract}

Keywords: Noise Mitigation; Traffic; Losari Beach Yard.

\footnotetext{
${ }^{1}$ Program Studi Arsitektur, Universitas Fajar

${ }^{2}$ Program Studi Arsitektur, Universitas Fajar

${ }^{3}$ Program Studi Arsitektur, Universitas Fajar
} 


\section{PENDAHULUAN}

Kota Makassar sebagai pusat pengembangan kawasan strategis di Wilayah Timur Indonesia dalam perkembangannya menghadirkan kawasan ruang publik yang mampu melayani kebutuhan masyarakat akan sebuah ruang sebagai sarana rekreatif untuk digunakan berinteraksi/kontak sosial dengan masyarakat kota lainnya sehingga meningkatkan kualitas kehidupan perkotaan baik dari segi lingkungan, masyarakat maupun kota melalui pemanfaatan ruang di dalamnya. Data Dinas Kebudayaan dan Pariwisata Kota Makassar menunjukkan, bahwa Pantai Losari sepanjang tahun 2006 sampai akhir tahun 2011 telah dikunjungi oleh wisatawan domestik sebanyak 10.668.719 orang. Sedang wisatawan mancanegara yang telah berkunjung ke Pantai Losari, tercatat sebanyak 145.157 orang.

Pelataran Pantai Losari dalam perkembangannya sebagai ruang terbuka binaan publik dalam konteks perkotaan perlu memperhatikan berbagai fakor yang berpengaruh didalamnya sehingga tercipta ruang luar yang responsif terhadap kebutuhan masyarakat. Salah satu faktor penyebab munculnya ketidaknyamanan pengunjung adalah kebisingan. Hal ini terjadi mengingat letak Pelataran Pantai Losari sangat dekat dengan aktifitas lalu lintas disamping sumber kebisingan lainnya. Sumber kebisingan lalu lintas berasal dari suara yang dihasilkan dari mesinmesin kendaraan, knalpot, klakson serta getaran yang timbul akibat interaksi antara roda dengan jalan. Selain itu intensitas kebisingan akibat kendaraan juga akan ditentukan berdasarkan jumlah dan kecepatan kendaraan yang melewati jalan.

Pengaruh buruk kebisingan, didefinisikan sebagai suatu perubahan morfologi dan fisiologi suatu organisma yang mengakibatkan penurunan kapasitas fungsional untuk mengatasi adanya stress tambahan atau peningkatan kerentanan suatu organisma terhadap pengaruh efek faktor lingkungan yang merugikan, termasuk pengaruh yang bersifat sementara maupun gangguan jangka panjang terhadap suatu organ atau seseorang secara fisik, psikologis atau sosial (Mansyur 2003). Berdasarkan hal tersebut diatas, maka dipandang perlu untuk melakukan perhitungan tingkat kebisingan di jalan raya guna mengetahui apakah tingkat kebisingan yang terjadi masih dapat ditolerir atau sudah melampaui ambang batas sehingga perlu dilakukan mitigasi dampak untuk menurunkan tingkat kebisingan hingga memenuhi ambang batas yang ditetapkan sesuai Keputusan Menteri Negara Lingkungan Hidup (1996) tentang baku mutu tingkat kebisingan. Upaya mitigasi tersebut dapat dilakukan baik secara parsial maupun kombinasi dari berbagai upaya lainnya.

Penelitian terdahulu Juniardi (2014), menyatakan sebaiknya bangunan atau fasilitas lainnya yang belum dibangun, diletakkan didaerah yang aman terhadap gangguan kebisingan atau jika dibangun di daerah pengaruh bising perlu diberikan pohon pelindung dan dinding sebagai alternative. Sedangkan untuk media perambatan pada ruang terbuka B dan Agata (2011), menyatakan media halaman rumput dan tanaman berair lebih baik dalam menyerap kebisingan yang terjadi dibanding media halaman seperti pasir dan paving blok. Pada permukaan keras (aspal atau paving block) tidak mampu menyerap gelombang bunyi yang merambat tetapi justru memantulkannya sehingga bunyi yang sampai ke suatu titik pada jarak tertentu dari sumber bunyi dapat menjadi lebih kuat. 
Tujuan dari penelitan ini yaitu (1) Mengidentifikasi tingkat kebisingan yang disebabkan oleh lalu lintas pada Ruang Terbuka Binaan Publik (RTBPU) Pelataran Pantai Losari; (2) Menganalisis pengaruh instrument mitigasi kebisingan lalu lintas terhadap tingkat kenyamanan pengunjung pada RTBPU Pelataran Pantai Losari. Adapun manfaat dari hasil penelitian ini diharapkan dapat (1) memberikan informasi bagi masyarakat dan pemerintah tentang besarnya nilai kebisingan pada RTBPU Pelataran Pantai Losari sehingga menjadi pertimbangan dalam penataan kedepannya demi kenyamanan pengunjung dan menjadi nilai tambah bagi peningkatan wisatawan domestic maupun internasional, (2) menjadi referensi bagi perencanaan ruang terbuka publik di kota besar khususnya pada pengurangan tingkat kebisingan.

\section{A. Jenis Ruang Terbuka}

Ruang terbuka (openspace) merupakan ruang yang dapat diakses oleh masyarakat baik secara langsung dalam kurun waktu terbatas maupun secarta tidak langsung dalam kurun waktu tidak tertentu. Ruang terbuka dapat berbentuk jalan, trotoar dan ruang terbuka hijau seperti taman kota, hutan dan sebagainya. Kawasan yang dicanangkan sebagai ruang terbuka dapat berupa kawasan diwilayah perkotaan, pedesaan, wilayah peralihan desa kota. Hakim (2012) membagi beberapa jenis ruang terbuka salah satunya RTB atau Ruang terbuka binaan (built openspaces). RTB terdiri dari ruang terbuka binaaan publik (RTBPU) yang lebih luas, baik dalam bentuk area memanjang yang lebih bersifat terbuka atau umum dan ruang terbuka binaan privat (RTBPV) penggunaanya lebih bersifat terbatas atau pribadi.

\section{B. Mitigasi Kebisingan Lalu Lintas}

Definisi dari mitigasi dampak kebisingan menurut dinas pekerjaan umum (2005) yaitu upaya-upaya yang dilakukan guna mengurangi sampai menghilangkan dampak negatif yang diperkirakan akan terjadi dan atau terjadi karena adanya aktivitas lalu lintas. Tata cara mitigasi dampak kebisingan akibat lalu lintas jalan yang meliputi penanganan pada sumber kebisingan, jalur perambatan dan penerima kebisingan. Adapun tujuan mitigasi kebisingan untuk menurunkan tingkat kebisingan hingga memenuhi ambang batas yang ditetapkan sesuai keputusan Menteri Lingkungan Hidup No.Kep-48/MENLH/11/1996 tentang baku mutu tingkat kebisingan.

Tabel 1. Baku Tingkat Kebisingan

\begin{tabular}{ll}
\hline \multicolumn{1}{c}{ Peruntukan Kawasan/ Lingkungan Kegiatan } & Tingkat Kebisingan dB(A) \\
\hline a. & Peruntukan Kawasan \\
1. Perumahan dan Permukiman & 55 \\
2. Perdagangan dan Jasa & 70 \\
3. Perkantoran dan perdagangan & 65 \\
4. Ruangan Terbuka Hijau & 50 \\
5. Industri & 70 \\
6. Pemerintahan dan Fasilitas Umum & 60 \\
7. Rekreasi & 70 \\
8. Khusus: & 60 \\
$\quad$ - Bandar Udara & - \\
$\quad$ - Stasiun Kereta Api & - \\
$\quad$ - Pelabuhan Laut & 70 \\
$\quad$ - Cagar Budaya & 60
\end{tabular}


Penanganan kebisingan pada jalur perambatan suara umumnya dilakukan dengan pemasangan Peredam Bising (PB). PB dapat berupa penghalang alami (natural barrier) dan penghalang buatan (artificial barrier). Penghalang alami biasanya menggunakan berbagai kombinasi tanaman dengan gundukan (berm) tanah, sedangkan penghalang buatan dapat dibuat dari berbagai bahan seperti: tembok, kaca, kayu, aluminium, dan bahan lainnya. Untuk mencapai kinerja yang memadai, bahan yang digunakan sebagai penghalang sebaiknya memiliki rasio berat-luas minimum $20 \mathrm{~kg} / \mathrm{m}^{2}$.

Mitigasi kebisingan harus mempertimbangkan faktor-faktor sebagai berikut:

1. Keselamatan pengguna jalan yang berkaitan dengan jarak pandang dan ketahanan konstruksi terhadap benturan;

2. Kemudahan pemeliharaan, termasuk bangunan yang ada di sekitarnya, seperti saluran drainase;

3. Stabilitas konstruksi dan usia layan mencapai 15 s.d. 20 tahun;

4. Biaya konstruksi yang tergantung pada jenis pondasi yang dibutuhkan dan metode konstruksi yang digunakan, perbandingan indikatif dari berbagai upaya mitigasi dapat dilihat pada tabel 2;

5. Keindahan atau estetika lingkungan di sekitarnya.

Tabel 2. Perbandingan indikatif dari berbagai upaya mitigasi

\begin{tabular}{|c|c|c|}
\hline Upaya & Efektifitas & Perbandingan Biaya \\
\hline Tanggul tanah & $\begin{array}{l}\text { Sama dengan jenis -jenis penghalang lainnya } \\
\text { seperti kayu atau beton; perlu tempat lebih }\end{array}$ & $\begin{array}{l}\text { Sangat murah apabila bahan timbunan } \\
\text { tersedia dilokasi }\end{array}$ \\
\hline $\begin{array}{l}\text { Beton, Kayu, logam atau } \\
\text { pagar penghalang lainnya }\end{array}$ & Baik; membutuhkan tempat lebih kecil & $\begin{array}{c}\text { Biayanya 10-100 kali dari tanggul tanah } \\
\text { namun dapat menghemat biaya lahan }\end{array}$ \\
\hline $\begin{array}{l}\text { Jalan bawah tanah (gali } \\
\text { dan tutup) }\end{array}$ & $\begin{array}{c}\text { Sebuah pilihan yang ekstrim bagi lalu lintas } \\
\text { yang padat sekali; memerlukan ventilasi } \\
\text { apabila panjang lebih } 300 \mathrm{~m}\end{array}$ & $\begin{array}{l}\text { Biayanya 10-16000 kali dari tanggul } \\
\text { tanah }\end{array}$ \\
\hline $\begin{array}{l}\text { Jendela kaca ganda untuk } \\
\text { selubung depan }\end{array}$ & $\begin{array}{c}\text { Baik namun hanya pada saat jendela tidak } \\
\text { dibuka tidak melindungi area-area luar }\end{array}$ & Biayanya 5-60 kali sebuah tanggul tanah \\
\hline
\end{tabular}

\section{Kenyamanan Akustik pada Ruang Terbuka}

Ruang terbuka memiliki karateristik akustik yang beragam berdasarkan peruntukannya, ruang terbuka yang terletak pada pusat kota akan sangat rentan terhadap kebisingan yang bersumber dari aktivitas warga ataupun kesibukan lalu-lintas. Tingkat kebisingan menurut keputusan Menteri Lingkungan Hidup No.Kep-48/MENLH/11/1996, untuk ruang terbuka dan fasilitas umum yaitu (1) Kawasan ruang terbuka hijau sebesar 50 dB(A); (2) Kawasan pemerintahan dan fasilitas umum sebesar $60 \mathrm{~dB}(\mathrm{~A})$ dan (3) Kawasan rekreasi sebesar 70 $\mathrm{dB}(\mathrm{A})$. sedangkat tingkat kenyamanan kebisingan yang dapat diterima yang juga direkomendasikan oleh U.S.Department of Housing and Urban Developmnet dapat dilihat pada tabel 3. Sangkertadi (2006) mengungkapkan kenyamanan pendengaran atau suara (sound 
comfort) selalu dihubungkan dengan tiga karakter tentang bunyi yakni: bunyi terlalu kuat yang menjadi bunyi bising (noise), bunyi gaung (echo sound) dan getaran yang mengganggu.

Pada ruang terbuka utamanya untuk area publik, sumber suara yang muncul baik secara natural maupun buatan tidak semuanya dapat dikategorikan sebagai sebuah kebisingan, hal ini disebabkan adanya keinginan manusia terhadap bunyi di tempat manapun sangat tergantung pada konteks. Zhang dan Kang (2007) mengungkapkan bunyi yang disukai orang pada suatu ruang publik secara umum sebagai berikut:

1. Air yang mengalir/berpindah (dalam segala wadah)

2. Suara-suara alam, burung dan hewan

3. Angina di pepohonan

4. Suara orang-orang (suara, langkah kaki, tertawa dan menyanyi) dan

5. Bunyi mesin (transportasi, mesin, ventilator)

Tabel 3. Tingkat Kebisingan Umum

\section{Tingkat Kebisingan Umum dB(A)}

Tidak dapat diterima:

Melebihi $80 \mathrm{~dB}(\mathrm{~A}), 60$ menit dalam 24 jam

Dapat dipilih atau tidak- biasanya tidak dapat diterima:

Melebihi $75 \mathrm{~dB}(\mathrm{~A}), 8$ jam dalam 24 jam Melebihi $65 \mathrm{~dB}(\mathrm{~A}), 8$ jam dalam 24 jam

Dapat dipilih atau tidak-biasanya dapat diterima:

Tidak melebihi $65 \mathrm{~dB}(\mathrm{~A})$, lebih dari 8 jam dalam 24 jam Suara-suara kuat yang berulang-ulang pada lokasi Dapat diterima:

Tidak melebihi $45 \mathrm{~dB}(\mathrm{~A})$, lebih dari 30 menit dalam 24 jam

Sumber: U.S Department of Transportation (1972) dalam Pemodelan Kebisingan (Nyayu dan Budi 2012)

\section{METODE}

\section{A. Tempat dan waktu penelitian}

Lokasi pengambilan data penelitian dilaksanakan di Pelataran Pantai Losari jalan Penghibur Kota Makassar, penelitian dilaksanakan pada 5 titik pengukuran selama 3 minggu, waktu pengukuran ialah pukul 07.00 sampai dengan pukul 23.00 WITA (Waktu Indonesia Tengah) dan pengolahan laporan penelitian dilaksanakan di kampus Universitas Fajar, dengan jangka waktu penelitian selama 6 bulan (Juni-November).

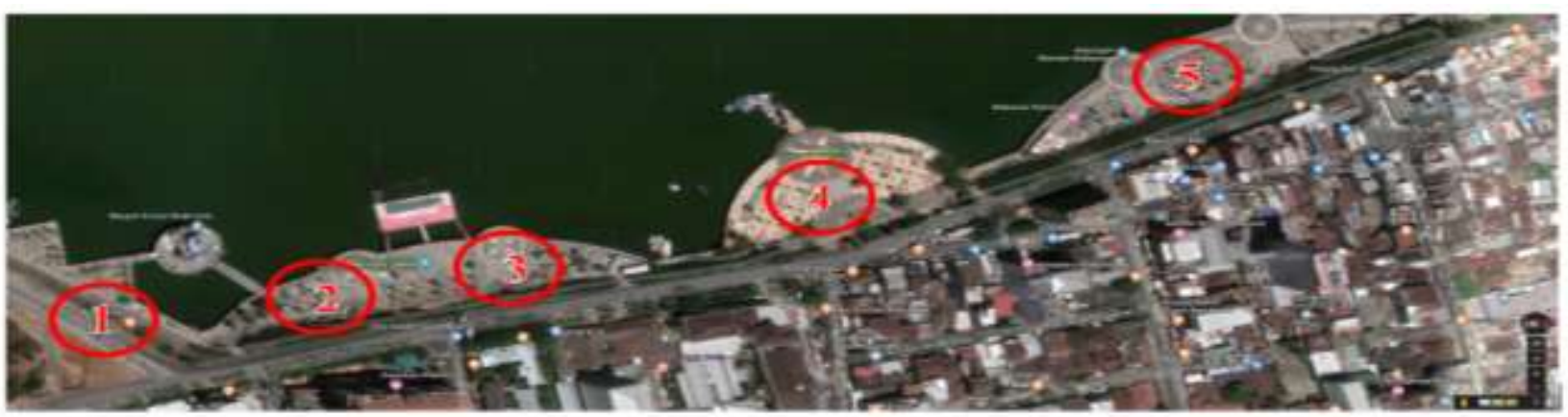

Gambar 1. Posisi Titik Ukur pada Pelataran Pantai Losari Sumber: Olah Desain, 2019

Keterangan:

Posisi titik ukur:

1. Gerbang Tanjung = Titik Ukur 1 (T1)

2. Plataran Makassar/F8 = Titik Ukur 2 (T2) 
3. Plataran Bugis $=$ Titik Ukur 3 (T3)

4. Plataran Bahari/Pantai Losari $=$ Titik Ukur 4 (T4)

5. Plataran Toraja-Mandar $=$ Titik Ukur 5 (T5)

\section{Waktu Pengambilan data}

Jam 07.00 wita mewakili jam 06.00 - 09.00 WITA Jam 10.00 wita mewakili jam 09.00 - 14.00 WITA Jam 15.00 wita mewakili jam 14.00 - 17.00 WITA Jam 20.00 wita mewakili jam 17.00 - 22.00 WITA Jam 23.00 wita mewakili jam 22.00 - 24.00 WITA

\section{B. Bahan dan alat}

Instrumen yang digunakan dalam penelitian ini berupa (1) Sound level meter untuk mengukur intensitas kebisingan, (2) Audiometer untuk mengukur nilai ambang dengar pada indera pendengaran, (3) Kuesioner, untuk mengetahui data pendukung penelitian. (4) Meteran untuk mengukur jarak, panjang, lebar dan tinggi. (5) Kamera untuk pemotretan obyek pengamatan. (6) Komputer untuk mengolah.

\section{Rancangan penelitian}

Jenis Penelitian ini menggunakan survey bersifat analitik dengan metode cross sectional. Populasi dalam penelitian ini masyarakat yang terpapar bising di wilayah Pelataran Pantai Losari. Sampel diambil dengan teknik quota sampling. Jumlah sampel dari masyarakat sekitar jalan raya sebanyak 40 orang pada masing-masing titik ukur.
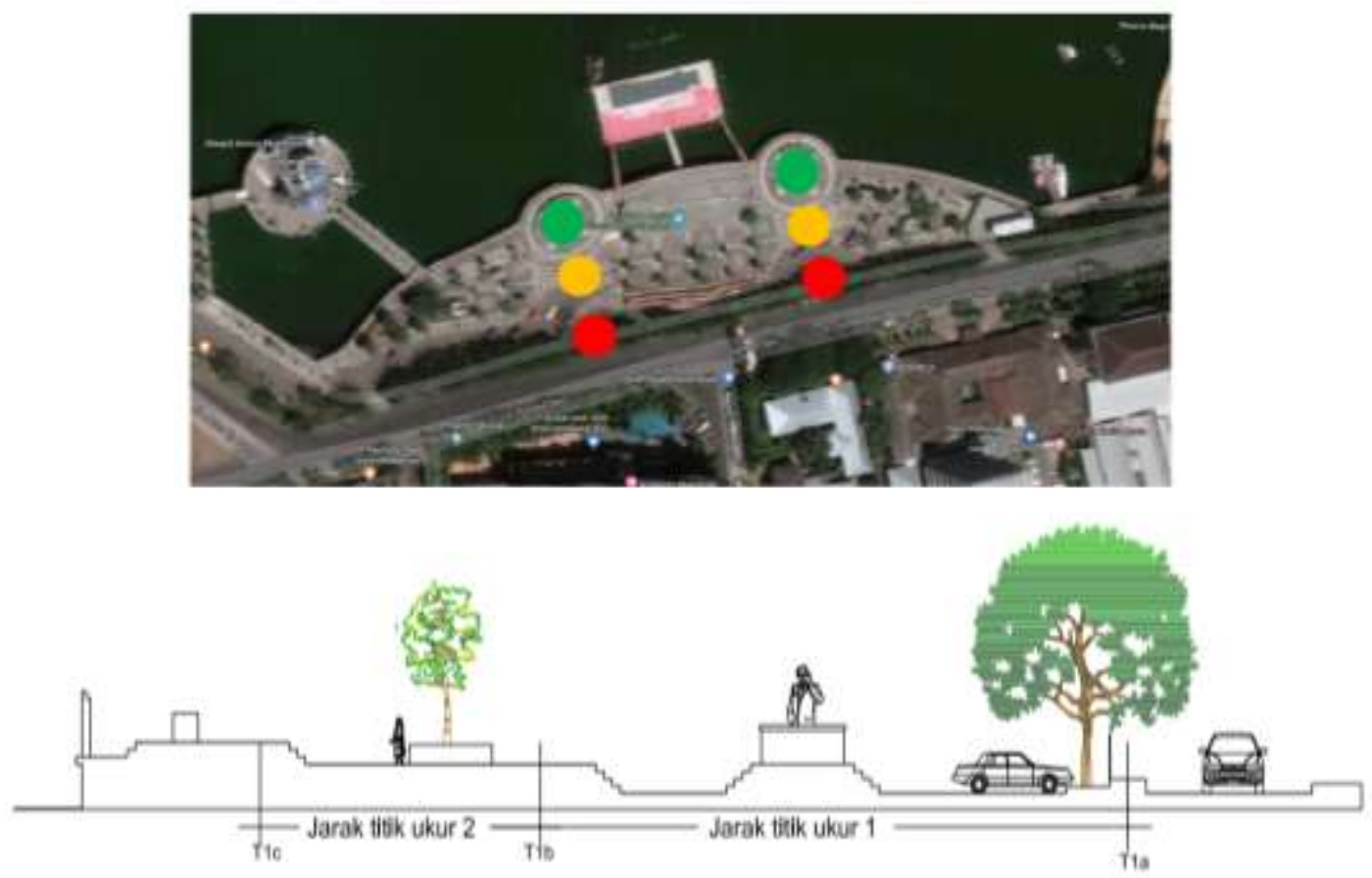

Gambar 2. Jarak Posisi Ukur Sumber: Olah Desian, 2019 
Pada tiap lokasi, pengukuran kebisingan dilakukan dengan menggunakan sepuluh buah alat ukur sound level meter secara bersamaan pada lima titik ukur, titik ukur A ditempatkan pada jarak 0 (nol) meterdari tepi badan jalan dan titik ukur B ditempatkan ditengah kawasan dengan jarak minimum 7 (tujuh) meter dari tepi badan jalan serta titik ukur C ditempatkan dengan jarak minimum 20 meter dari tepi badan jalan. Untuk dapat membandingkan tingkat kebisingan pada kedua lokasi tersebut maka pengukuran harus dilakukan dengan jarak dan ketinggian yang sama. Ukuran ketinggian ditetapkan masing-masing satu meter. Sumber bising adalah suara kendaraan bermotor yang melintas di Pelataran Pantai Losari.

Pengolahan data kebisingan akan diperoleh dari tingkat tekanan suara ekivalen (Leq), tingkat tekanan suara ekivalen pada siang hari (LS), tingkat tekanan suara ekivalen pada malam hari (LM), dan tingkat tekanan suara ekivalen selama siang dan malam hari (LSM). Adapun rumus perhitungan merunut pada standar perhitungan rumus KepMenLH (1996) :

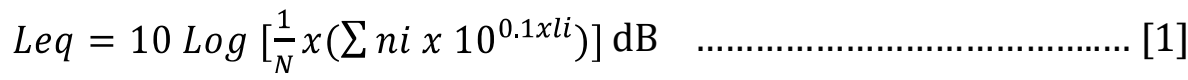

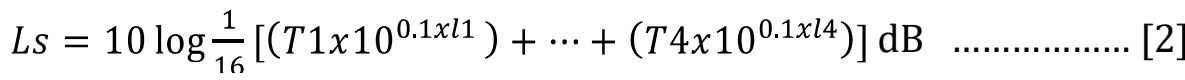

$$
\begin{aligned}
& L m=10 \log \frac{1}{8}\left[\left(T 5 \times 10^{0.1 \times l 5}\right)+\cdots+\left(T 7 \times 10^{0.1 x l 7}\right)\right] \mathrm{dB} \quad \ldots \ldots \ldots \ldots \ldots \ldots \ldots \ldots \\
& L s m=10 \log \frac{1}{24}\left(16 \times 10^{0.1 \times l s}+8 \times 10^{0.1(L m+5)}\right) \mathrm{dB}
\end{aligned}
$$

Keterangan:

Ls = Leq selama siang hari

LM $=$ Leq selama malam hari

LsM = Leq selama siang dan malam hari

$n_{i}=$ selang waktu pengukuran pada masing-masing $L i$.

Analisis data redusi kebisingan untuk instrument mitigasi vegetasi menggunakan rumus Widagdo (1998):

$$
N R V=K D V-K B V
$$

Keterangan:

NRV = Nilai reduksi kebisingan pada area bervegetasi (dBA)

$\mathrm{KDV}=$ Tingkat kebisingan di titik pengamatan area depan vegetasi $(\mathrm{dBA})$

$\mathrm{KBV}=$ Tingkat kebisingan di titik pengamatan area belakang vegetasi $(\mathrm{dBA})$

$$
N R T=K D T-K B T
$$

Keterangan:

NRT = Nilai reduksi kebisingan pada daerah terbuka $(\mathrm{dBA})$

KDT = Tingkat kebisingan di titik pengamatan depan daerah terbuka. Sejajar titik pengamatan depan daerah bervegetasi (dBA) 
KBT = Tingkat kebisingan di titik pengamatan belakang daerah terbuka, sejajar titik pengamatan belakang daerah bervegetasi (dBA)

Efektivitas reduksi dengan rumus:

Efektivitas Reduksi $(E R)=\frac{N R V-N R T}{K D V} X 100 \%$

Menghitung reduksi kebisingan oleh vegetasi dengan memperhatikan volume kerimbunan daun yang dihitung berdasarkan ketentuan Dinas Pekerjaan Umum (2005) dalam tabel 4, ketentuan rumus berlaku untuk 100\% kerimbunan, jika kurang maka nilai volume kerimbunan daun harus dikalikan dengan nilai persen kerimbunan daunnya.

Tabel 4. Volume kerimbunan daun sesuai bentuk kanopi

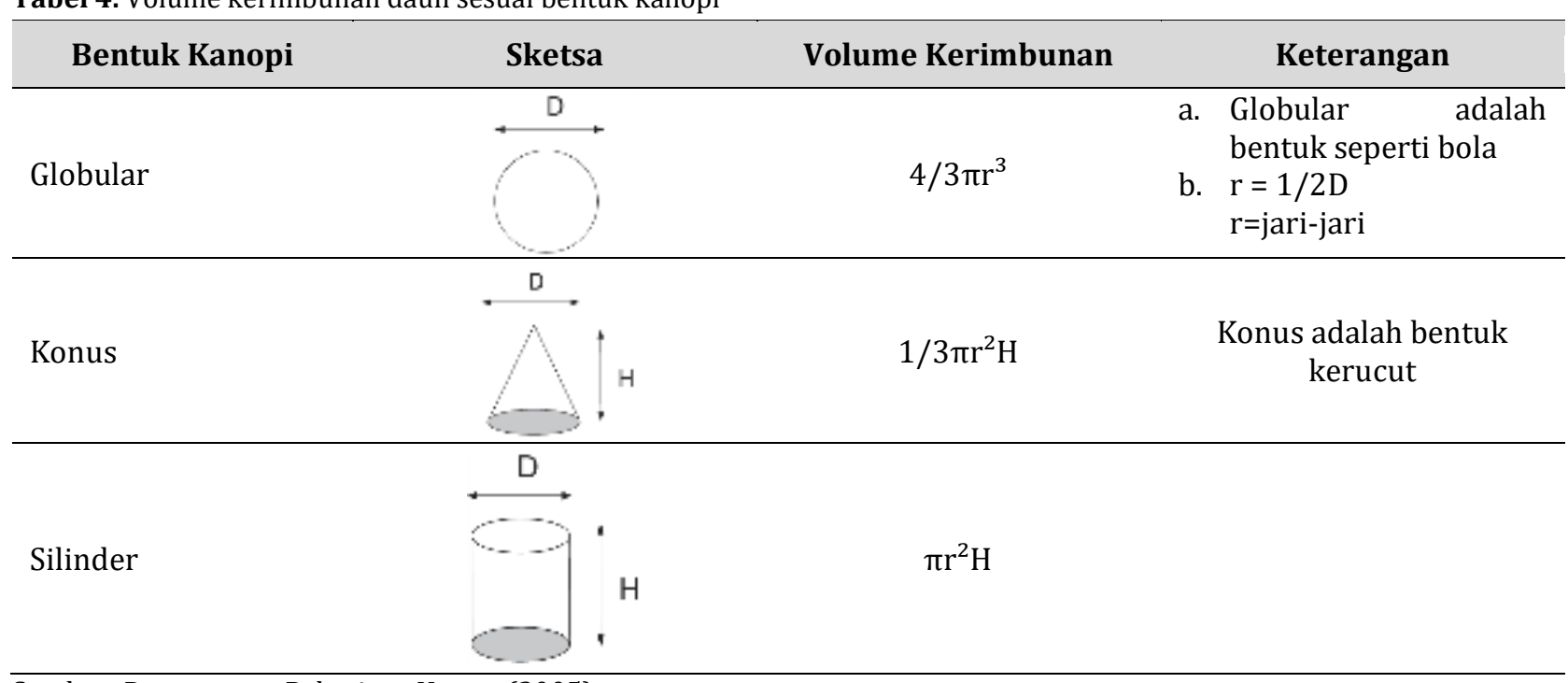

Sumber: Departemen Pekerjaan Umum (2005)

\section{HASIL DAN PEMBAHASAN}

\section{A. Aktivitas pengunjung Pelataran Pantai Losari dan karateristik responden}

Pelataran Pantai Losari yang berfungsi sebagai ruang binaan publik dalam kesehariannya diluar waktu libur (Senin-Sabtu) tidak lepas dari ramainya aktivitas pengunjung. Waktu pengunjung terpadat dapat dibagi kedalam dua periode waktu, yaitu: (1) waktu pagi hari (jam 05.00 -10.00 wita) berupa aktivitas olahraga santai, sedangkan (2) waktu sore hari (15.00 23.00 WITA) berupa aktivitas publik. Pada waktu libur (Minggu) terdapat aktivitas khusus (car free day) dengan kepadatan pengunjung dengan kegiatan olahraga, perniagaan, dan aktivitas publik lainnya.

Tabel 5. Distribusi frekuensi karateristik berdasarkan umur dan jenis kelamin pengunjung Pelataran Pantai Losari

\begin{tabular}{lcc}
\hline \multicolumn{1}{r}{ Karakteristik } & Frekuensi (n) & Persen (\%) \\
\hline Umur & & 30,5 \\
$<20$ tahun & 61 & 62,5 \\
20 -30 tahun & 125 & 7
\end{tabular}




\begin{tabular}{lcc}
\hline \multicolumn{1}{c}{ Karakteristik } & Frekuensi (n) & Persen (\%) \\
\hline Jenis kelamin & 79 & \\
Laki-laki & 121 & 39,5 \\
Perempuan & 60,5 \\
\hline
\end{tabular}

Hasil pengumpulan kuesioner pengunjung Pantai Losari dengan jumlah responden sebanyak 200 orang (tabel 5) dengan data karateristik umur responden $<20$ tahun sebanyak 61 orang $(30,5 \%)$ untuk umur $>30$ tahun sebanyak 14 orang $(7 \%)$ dan yang terbanyak pada kisaran umur 20-30 tahun sebesar 125 orang $(62,5 \%)$. Sedangkan data karateristik jenis kelamin responden laki-laki sebanyak 79 orang $(39,5 \%)$ dan perempuan 121 orang $(60,5 \%)$.

\section{B. Sumber bising dan Tingkat Kebisingan Pelataran Pantai Losari}

Data kebisingan Pelataran Pantai Losari dibaca setiap 5 detik selama 10 menit sehingga dihasilkan sebanyak 120 data dalam satu titik pengukuran. Pengukuran kebisingan dilakukan berdasarkan Kepmen-LH No. 48 tahun 1996 dan SNI 7231- 2009. Pengukuran kebisingan menggunakan alat sound level meter (SLM). Adapun rangkuman data tingkat kebisingan disajikan dalam tabel 6, dibagi berdasarkan kebisingan pada siang hari (Ls), kebisingan pada malam hari (Lm) dan kebisingan selama satu hari (Lsm).

Tabel 6. Tingkat kebisingan rata-rata sing-malam di Pelataran Pantai Losari

\begin{tabular}{|c|c|c|c|c|c|c|c|c|c|c|c|c|c|}
\hline \multirow{3}{*}{\multicolumn{2}{|c|}{ Titik ukur }} & \multicolumn{12}{|c|}{ Tingkat Kebisingan (dBA) } \\
\hline & & \multicolumn{3}{|c|}{ Jumat, 03/08/2018 } & \multicolumn{3}{|c|}{ Sabtu, 04/08/2018 } & \multicolumn{3}{|c|}{ Minggu, 05/08/2018 } & \multicolumn{3}{|c|}{ Rata-rata } \\
\hline & & Ls & $\mathrm{Lm}$ & Lsm & Ls & $\mathrm{Lm}$ & Lsm & Ls & $\mathrm{Lm}$ & Lsm & Ls & $\mathrm{Lm}$ & Lsm \\
\hline \multirow{3}{*}{$\mathrm{T} 1$} & T1a & 79.10 & 78.40 & 78.88 & 79.83 & 82.46 & 80.89 & 80.57 & 71.73 & 79.08 & 79.83 & 77.53 & 79.62 \\
\hline & $\mathrm{T} 1 \mathrm{~b}$ & 68.10 & 69.29 & 68.53 & 66.51 & 69.04 & 67.52 & 68.12 & 67.65 & 67.97 & 67.58 & 68.66 & 68.01 \\
\hline & T1c & 71.64 & 71.40 & 71.56 & 69.05 & 66.83 & 68.43 & 61.35 & 66.94 & 64.08 & 67.35 & 68.39 & 68.02 \\
\hline \multirow{3}{*}{$\mathrm{T} 2$} & $\mathrm{~T} 2 \mathrm{a}$ & 74.33 & 85.36 & 81.23 & 73.71 & 82.80 & 78.99 & 74.40 & 80.84 & 77.70 & 74.15 & 83.00 & 79.30 \\
\hline & $\mathrm{T} 2 \mathrm{~b}$ & 71.19 & 73.76 & 72.23 & 71.40 & 71.99 & 71.61 & 78.63 & 67.06 & 77.01 & 73.74 & 70.94 & 73.62 \\
\hline & T2c & 72.94 & 71.71 & 72.56 & 70.02 & 67.93 & 69.43 & 81.30 & 63.72 & 79.58 & 74.75 & 67.79 & 73.86 \\
\hline \multirow{3}{*}{ T3 } & T3a & 81.12 & 87.05 & 84.07 & 79.82 & 83.47 & 81.40 & 75.74 & 74.94 & 75.49 & 78.89 & 81.82 & 80.32 \\
\hline & T3b & 75.16 & 70.37 & 74.06 & 71.08 & 71.17 & 71.11 & 81.26 & 72.07 & 79.75 & 75.83 & 71.20 & 74.97 \\
\hline & T3c & 66.48 & 75.28 & 71.52 & 63.50 & 69.18 & 66.29 & 75.80 & 65.68 & 74.25 & 68.59 & 70.04 & 70.68 \\
\hline \multirow{3}{*}{$\mathrm{T} 4$} & $\mathrm{~T} 4 \mathrm{a}$ & 84.00 & 74.90 & 82.50 & 83.90 & 81.12 & 83.16 & 76.12 & 73.05 & 75.31 & 81.34 & 76.36 & 80.32 \\
\hline & $\mathrm{T} 4 \mathrm{~b}$ & 69.82 & 71.94 & 70.65 & 63.66 & 67.69 & 65.45 & 71.13 & 66.49 & 70.06 & 68.20 & 68.71 & 68.72 \\
\hline & $\mathrm{T} 4 \mathrm{c}$ & 74.75 & 70.62 & 73.75 & 65.90 & 66.67 & 66.17 & 70.73 & 63.99 & 69.41 & 70.46 & 67.09 & 69.78 \\
\hline \multirow{3}{*}{ T5 } & T5a & 77.78 & 78.69 & 78.11 & 81.08 & 79.71 & 80.67 & 78.32 & 81.58 & 79.70 & 79.06 & 80.00 & 79.49 \\
\hline & $\mathrm{T} 5 \mathrm{~b}$ & 74.60 & 66.50 & 73.16 & 72.69 & 73.99 & 73.17 & 77.01 & 70.48 & 75.71 & 74.77 & 70.33 & 74.01 \\
\hline & T5c & 71.26 & 65.08 & 70.00 & 62.52 & 71.11 & 67.40 & 70.84 & 66.30 & 69.78 & 68.21 & 67.49 & 69.06 \\
\hline
\end{tabular}

Keterangan:

Ls = Leq selama siang hari

LM = Leq selama malam hari

LSM = Leq selama siang dan malam hari

Gerbang Tanjung = Titik Ukur 1 (T1)

Pelataran Makassar/F8 = Titik Ukur 2 (T2)

Pelataran Bugis $=$ Titik Ukur 3 (T3)

Pelataran Bahari/Pantai Losari = Titik Ukur 4 (T4)

Pelataran Toraja-Mandar = Titik Ukur 5 (T5)

Tingkat kebisingan rata-rata yang dihasilkan dari pengukuran Pelataran Pantai Losari selama 3 hari pengukuran yang mewakili hari pada aktivitas terpadat yaitu hari Jumat, Sabtu dan Minggu, pada 5 (lima) lokasi titik ukur berada dalam rentang kebisingan satu hari (Lsm) 
yaitu 68,01 $\mathrm{dB}(\mathrm{A})$ - 80,32 $\mathrm{dB}(\mathrm{A})$, dimana tingkat kebisingan terendah berada pada titik ukur T1b dan tertinggi pada titik ukur T3a dan T4a. Rentang kebisingan pada siang hari (Ls) yaitu 67.35 $\mathrm{dB}(\mathrm{A})$ - 81,34 $\mathrm{dB}(\mathrm{A})$, dengan tingkat kebisingan terendah pada titik ukur T1c dan tertinggi pada titik ukur T4a. sedangkan pada malam hari (Lm) berada pada rentang 67,09 $\mathrm{dB}(\mathrm{A})$ - 83,00 $\mathrm{dB}(\mathrm{A})$, dimana tingkat kebisingan terendah berada pada titik ukur T4c dan tertinggi pada titik ukur T2a .

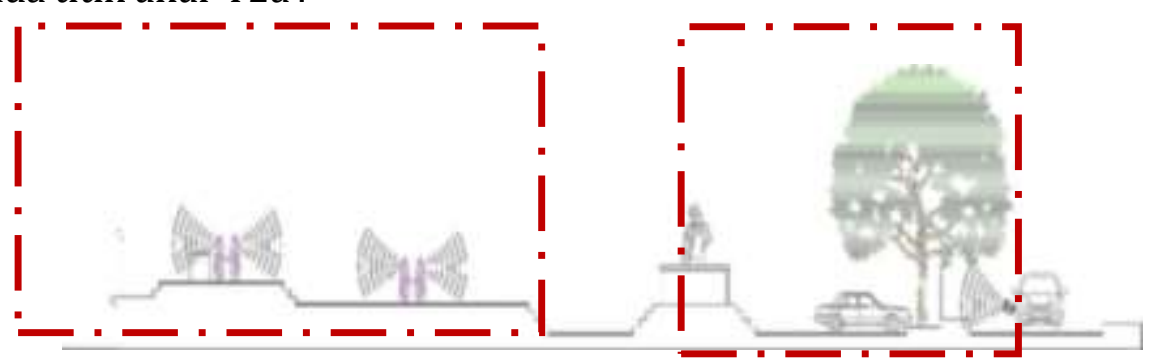

(a) Sumber kebisingan di titik ukur T2 dan T3 Pelataran Pantai Losari

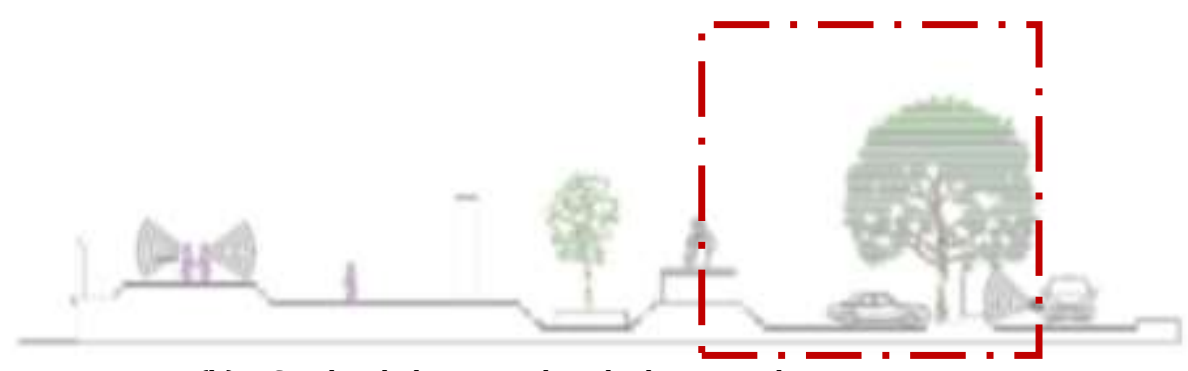

(b) Sumber kebisingan di titik ukur T4 Pelataran Pantai Losari

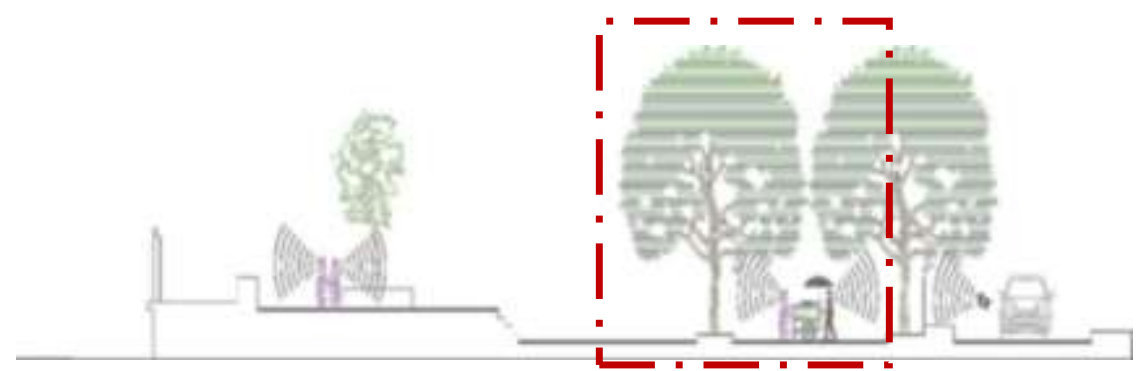

(c) Sumber kebisingan di titik ukur T5 Pelataran Pantai Losari

Gambar 3. Sumber Kebisingan Hasil Perhitungan Lsm,Ls, dan Lm

Hasil dari perhitungan tingkat kebisingan dalam satu hari (Lsm), pada siang hari (Ls), dan pada malam hari (Lm) menunjukkkan bahwa sumber kebisingan terbesar pada titik ukur T2a, T3a dan T4aberupa kebisingan dari aktivitas lalu lintas, hal ini disebabkan jarak titik ukur dekat dengan sumber kebisingan/berada pada bahu jalan (lihat gambar 3a dan 3b). sedangkan untuk sumber kebisingan terbesar berada pada titik ukur T2c, T3b dan T5b (lihat gambar 3a dan 3c) yang berasal dari aktivitas pengunjung Pelataran Pantai Losari, seperti berbicara, bermain, berteriak, dan berfoto. 


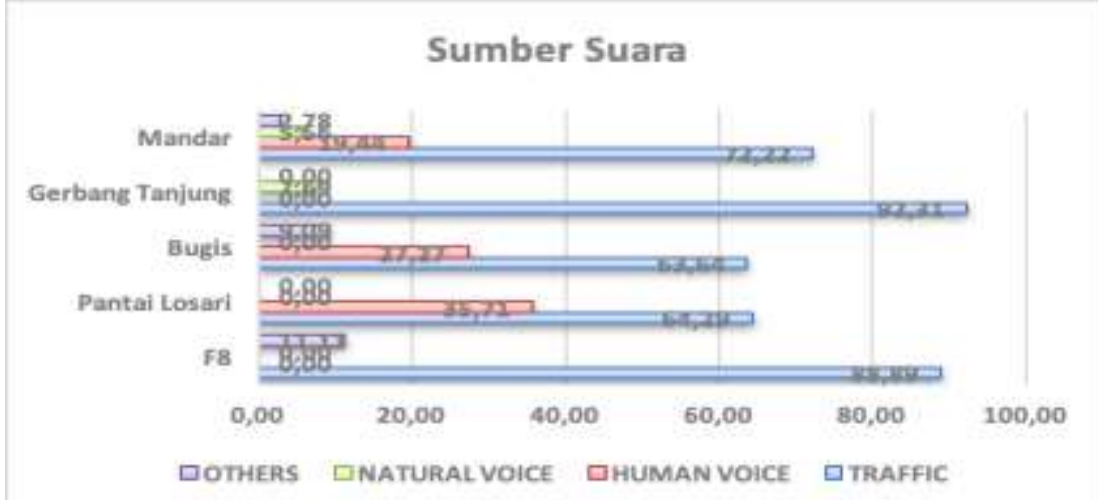

Gambar 4. Sumber kebisingan Pelataran Pantai Losari Hasil Kuesioner Pengunjung

Sumber kebisingan dari hasil data kuesioner pengunjung Pelataran Pantai Losari (gambar 4) menunjukkan bahwa sumber kebisingan terbesar berada pada titik ukur T1, gerbang Tanjung yaitu 92,31\% berasal dari aktivitas lalu lintas. Sumber kebisingan terbesar yang berasal dari aktivitas manusia terdapat pada titik ukur T4, Pelataran Bahari/Pantai Losari sebesar 35,71\%. Sedangkan sumber kebisingan yang berasal dari alam sekitar terbesar juga berada pada titik ukur T1, Gerbang Tanjung yaitu 7,69\%. Adapun sumber kebisingan terbesar dari kegiatan lainnya terdapat pada titik ukur T2 Pelataran Makassar/F8 sebesar 11,11\%.

\section{Elemen-elemen mitigasi kebisingan pada Pelataran Pantai Losari}

Hasil identifikasi penelitian dilapangan menunjukkan data instrument mitigasi kebisingan yang terdapat pada Pelataran Pantai Losari berupa pohon, rumput penutup taman, gindukan tanah, furniture landscape (pot bunga, bangku taman, sclupture) dan perkerasan (lantai plaza, paving parkiran). Adapun jenis pohon yang telah didata menjadi instrumen mitigasi kebisingan pada Pelataran Pantai Losari berupa palem, trembesi/ki hujan, tanaman perdu, ketapang kencana, pohon kelapa dan beringin. Data volume kerimbunan pohon dan jenis elemen lainnya tercatat dalam tabel 7.

Tabel 7. Instrumen Mitigasi Kebisingan Pelataran Pantai Losari

\begin{tabular}{|c|c|c|c|c|c|c|}
\hline $\begin{array}{l}\text { Titik } \\
\text { Ukur }\end{array}$ & Elemen Mitigasi & Jenis & $\begin{array}{c}\text { Vol } \\
\text { Satuan } \\
\text { (M3) }\end{array}$ & Jumlah & $\begin{array}{l}\text { Vol } \\
\text { Total } \\
\text { (M3) } \\
\end{array}$ & Fungsi Mitigasi \\
\hline \multirow{4}{*}{$\mathrm{T} 1$} & & Pohon Beringin & 65.4 & 2 & 130.83 & Menyerap suara \\
\hline & & $\begin{array}{l}\text { Pohon Trembesi/Ki } \\
\text { Hujan depan jalan }\end{array}$ & 2.65 & 20 & 53.07 & Menyerap suara \\
\hline & & $\begin{array}{l}\text { Pohon Beringin dalam } \\
\text { plaza }\end{array}$ & 2.01 & 8 & 16.08 & Menyerap suara \\
\hline & & Pohon kelapa dalam & 1.07 & 9 & 9.65 & Menyerap suara \\
\hline \multirow{4}{*}{$\mathrm{T} 1$} & \multirow{4}{*}{ F 8} & Pot beton + tanah & 0.93 & 10 & 9.34 & $\begin{array}{c}\text { Menyerap/mema } \\
\text { ntul suara }\end{array}$ \\
\hline & & Sculpture beton & 4.24 & 3 & 12.72 & $\begin{array}{c}\text { Menyerap/mema } \\
\text { ntul suara }\end{array}$ \\
\hline & & Rumput taman & 0.14 & 4 & 0.58 & Menyerap suara \\
\hline & & Tempat duduk & 0.9 & 4 & 3.6 & $\begin{array}{c}\text { Menyerap/mema } \\
\text { ntul suara }\end{array}$ \\
\hline $\mathrm{T} 2$ & & Sculpture beton & 0.50 & 1 & 0.50 & $\begin{array}{c}\text { Menyerap/mema } \\
\text { ntul suara }\end{array}$ \\
\hline
\end{tabular}




\begin{tabular}{|c|c|c|c|c|c|c|}
\hline $\begin{array}{l}\text { Titik } \\
\text { Ukur }\end{array}$ & Elemen Mitigasi & Jenis & $\begin{array}{c}\text { Vol } \\
\text { Satuan } \\
\text { (M3) }\end{array}$ & Jumlah & $\begin{array}{l}\text { Vol } \\
\text { Total } \\
\text { (M3) } \\
\end{array}$ & Fungsi Mitigasi \\
\hline & & Sculpture beton + ACP & 5.40 & 1 & 5.40 & $\begin{array}{c}\text { Menyerap/mema } \\
\text { ntul suara }\end{array}$ \\
\hline & & $\begin{array}{c}\text { Sculpture tulisan } \\
\text { beton }\end{array}$ & 4.68 & 1 & 4.68 & $\begin{array}{c}\text { Menyerap/mema } \\
\text { ntul suara }\end{array}$ \\
\hline & & $\begin{array}{l}\text { Pohon Trembesi/Ki } \\
\text { Hujan depan jalan }\end{array}$ & 6.03 & 20 & 120.58 & Menyerap suara \\
\hline \multirow{3}{*}{ T3 } & & Sculpture beton & 0.50 & 1 & 0.50 & $\begin{array}{l}\text { Menyerap/mema } \\
\text { ntul suara }\end{array}$ \\
\hline & & $\begin{array}{l}\text { Sculpture tulisan } \\
\text { beton }\end{array}$ & 2.73 & 1 & 2.73 & $\begin{array}{l}\text { Menyerap/mema } \\
\text { ntul suara }\end{array}$ \\
\hline & & $\begin{array}{l}\text { Pohon Trembesi/Ki } \\
\text { Hujan depan jalan }\end{array}$ & 6.03 & 18 & 108.52 & Menyerap suara \\
\hline \multirow{6}{*}{$\mathrm{T} 4$} & & Sculpture beton & 0.5 & 1 & 0.5 & $\begin{array}{c}\text { Menyerap/mema } \\
\text { ntul suara }\end{array}$ \\
\hline & & $\begin{array}{l}\text { Sculpture beton } \\
\text { adipura }\end{array}$ & 90 & 2 & 180 & $\begin{array}{c}\text { Menyerap/mema } \\
\text { ntul suara }\end{array}$ \\
\hline & & $\begin{array}{l}\text { Taman segitiga } \\
\text { dalam }\end{array}$ & 10.08 & 2 & 20.16 & Menyerap suara \\
\hline & & $\begin{array}{l}\text { Taman segitiga depan } \\
\text { jalan }\end{array}$ & 10.8 & 3 & 32.40 & Menyerap suara \\
\hline & & Pohon Kelapa & 65.42 & 6 & 294.38 & Menyerap suara \\
\hline & & $\begin{array}{c}\text { Pohon Trembesi/Ki } \\
\text { Hujan }\end{array}$ & 84.78 & 7 & 593.46 & Menyerap suara \\
\hline \multirow{8}{*}{ T5 } & & $\begin{array}{c}\text { Pohon Trembesi/Ki } \\
\text { hujan dekat jalan }\end{array}$ & 25.12 & 6 & 150.72 & Menyerap suara \\
\hline & & $\begin{array}{c}\text { Pohon Ketapang } \\
\text { Kencana dalam plaza }\end{array}$ & 0.59 & 15 & 8.83 & Menyerap suara \\
\hline & & $\begin{array}{l}\text { Sculpture tulisan } \\
\text { beton }\end{array}$ & 2.73 & 1 & 2.73 & $\begin{array}{c}\text { Menyerap/mema } \\
\text { ntul suara }\end{array}$ \\
\hline & & $\begin{array}{l}\text { Pohon Trembesi/Ki } \\
\text { Hujan (trotoar dalam) }\end{array}$ & 49.06 & 6 & 294.38 & Menyerap suara \\
\hline & & Bangku taman & 0.72 & 15 & 10.80 & $\begin{array}{l}\text { Menyerap/mema } \\
\text { ntul suara }\end{array}$ \\
\hline & & Rumput taman & 0.14 & 15 & 2.16 & Menyerap suara \\
\hline & & Pohon Palem & 1.26 & 4 & 5.02 & Menyerap suara \\
\hline & $2 x+2=9$ & Area jualan & 1744 & 1 & 1744 & $\begin{array}{c}\text { Menyerap/mema } \\
\text { ntul suara }\end{array}$ \\
\hline
\end{tabular}

Sumber: Hasil Survey, 2019

Instrument mitigasi kebisingan yang terdapat pada Pelataran Pantai Losari memiliki sifatsifat yang berbeda dalam fungsinya sebagai mitigasi kebisingan bergantung dari material ataupun bahan-bahan pembentuknya. Beberapa instrument seperti pohon, rumput penutup tanah, gundukan tanah lebih berperan sebagai peredam ataupun menyerap dari suara kebisingan. Sedangkan material seperti beton sebagian menyerap dan sebagian pula memantulkan suara kebisingan yang ada.

Pada jam tertentu utamanya pada sore hingga malam hari beberapa posisi titik ukur (titik ukur T5 dan titik ukur T1) terdapat aktivitas perdagangan didepan jalan utama Pelataran Pantai 
Losari. Kepadatan pengunjung yang beraktivitas diarea perdagangan ini menjadi salah satu pengamatan dalam menentukan instrument mitigasi kebisingan di Pelataran Pantai Losari.

\section{Tingkat Reduksi dari instrument Mitigasi kebisingan Pelataran Pantai Losari}

Perhitungan reduksi kebisingan dan efektivitas dari instrument mitigasi kebisingan yang terdapat pada Pelataran Pantai Losari terangkum dalam tabel 8. Rata-rata dari hasil perhitungan nilai reduksi kebisingan pada area bervegetasi (NRV) terendah sebesar 5.48 (dBA) pada titik ukur T5 dan nilai terbesar 11.61(dBA) pada titik ukur T1 dan T4. Nilai reduksi kebisingan pada daerah terbuka (NRT) terendah sebesar 5.45 (dBA) pada titik ukur T2 dan nilai terbesar 11.60 (dBA) pada titik ukur T1. Adapun nilai efektifitas Reduksi (ER) oleh vegetasi terendah sebesar $6.2 \%$ pada titik ukur T5 dan tertinggi sebesar 1.3\% pada titik ukur T4. Terdapat hasil negative dari nilai efektifitas reduksi pada beberapa titik ukur salah satunya titik ukur T5. Hal ini disebabkan pada angka pengurangan nilai reduksi kebisingan pada daerah terbuka lebih besar dari reduksi kebisingan pada area bervegetasi.

Tabel 8. Reduksi kebisingan dan efisiensi reduksi kebisingan rata-rata (dalam 3 hari pengukuran) berdasarkan jarak dan posisi titik ukur

\begin{tabular}{|c|c|c|c|c|c|c|c|}
\hline \multirow[b]{2}{*}{$\begin{array}{l}\text { Titik } \\
\text { ukur }\end{array}$} & \multicolumn{2}{|c|}{ Jarak Ukur (m) } & \multirow[b]{2}{*}{$\begin{array}{l}\text { Reduksi } \\
\text { Kebisingan }\end{array}$} & \multicolumn{4}{|c|}{ Hari Pengukuran } \\
\hline & NRV & NRT & & $\begin{array}{l}\text { Jumat, } \\
03 / 08 / 18\end{array}$ & $\begin{array}{c}\text { Sabtu, } \\
04 / 08 / 18\end{array}$ & $\begin{array}{c}\text { Minggu, } \\
05 / 08 / 18\end{array}$ & Rata-rata \\
\hline \multirow{3}{*}{$\mathrm{T} 1$} & \multirow{3}{*}{15.64} & \multirow{3}{*}{32.91} & NRV (dBA) & 10.35 & 13.37 & 11.11 & 11.61 \\
\hline & & & NRT (dBA) & 7.32 & 12.47 & 15.00 & 11.60 \\
\hline & & & ER (\%) & 3.8 & 1.1 & -4.9 & 0.00 \\
\hline \multirow{3}{*}{$\mathrm{T} 2$} & \multirow{3}{*}{13.87} & \multirow{3}{*}{54.18} & NRV (dBA) & 9.00 & 7.38 & 0.68 & 5.69 \\
\hline & & & NRT (dBA) & 8.66 & 9.57 & -1.89 & 5.45 \\
\hline & & & ER (\%) & 0.4 & -2.8 & 3.3 & 0.3 \\
\hline \multirow{3}{*}{$\mathrm{T} 3$} & \multirow{3}{*}{7.86} & \multirow{3}{*}{51.62} & NRV (dBA) & 10.01 & 10.29 & 4.26 & 8.19 \\
\hline & & & NRT (dBA) & 12.55 & 15.11 & 1.24 & 9.63 \\
\hline & & & ER (\%) & -3.0 & -5.9 & -7.3 & -5.4 \\
\hline \multirow{3}{*}{$\mathrm{T} 4$} & \multirow{3}{*}{45.96} & \multirow{3}{*}{90.34} & NRV (dBA) & 11.85 & 17.71 & 5.26 & 11.61 \\
\hline & & & NRT (dBA) & 8.75 & 16.98 & 5.90 & 10.54 \\
\hline & & & ER (\%) & 3.8 & 0.9 & -0.9 & 1.3 \\
\hline \multirow{3}{*}{ T5 } & \multirow{3}{*}{12.05} & \multirow{3}{*}{54.06} & NRV (dBA) & 4.95 & 7.50 & 3.99 & 5.48 \\
\hline & & & NRT (dBA) & 8.11 & 13.27 & 9.91 & 10.43 \\
\hline & & & ER (\%) & -4.1 & -7.2 & -7.4 & -6.2 \\
\hline
\end{tabular}

Sumber: Hasil Analisis, 2019

Volume instrument mitigasi kebisingan Pelataran Pantai Losari (tabel 9) terbesar $2218.64 \mathrm{~m}^{3}$ berada pada titik ukur $\mathrm{T} 5$, dengan perbandingan instrument mitigasi kebisingan berupa vegetasi/gundukan tanah $20,8 \%$, beton/bata $0,6 \%$ dan penghalang (barrier) berupa area jualan/perdagangan 78,6\%. Adapun volume instrument mitigasi kebisingan terendah berada pada titik T2, dengan perbandingan instrument mitigasi vegetasi/gundukan tanah 91.9\% dan beton/bata $8,1 \%$.

Tabel 9. Efektifitas reduksi kebisingan

\begin{tabular}{|c|c|c|c|c|c|c|c|c|}
\hline \multirow[b]{2}{*}{$\begin{array}{l}\text { Titik } \\
\text { ukur }\end{array}$} & \multicolumn{2}{|c|}{ Jarak Ukur (m) } & \multirow{2}{*}{\multicolumn{2}{|c|}{$\begin{array}{l}\text { Reduksi Kebisingan } \\
\text { (Rata-rata) }\end{array}$}} & \multicolumn{4}{|c|}{ Volume instrument mitigasi $\left(\mathrm{m}^{3}\right)$} \\
\hline & NRV & NRT & & & $\begin{array}{c}\text { Vegetasi/ } \\
\text { Gundukan } \\
\text { tanah }\end{array}$ & Beton / Bata & $\begin{array}{l}\text { Area } \\
\text { jualan }\end{array}$ & Total \\
\hline $\mathrm{T} 1$ & 15.64 & 32.91 & $\frac{\text { NRV (dBA) }}{\text { NRT (dBA) }}$ & $\frac{11.61}{11.60}$ & 222.34 & 25.66 & - & 248 \\
\hline
\end{tabular}




\begin{tabular}{|c|c|c|c|c|c|c|c|c|}
\hline \multirow{3}{*}{$\begin{array}{l}\text { Titik } \\
\text { ukur }\end{array}$} & \multicolumn{2}{|c|}{ Jarak Ukur (m) } & \multirow{2}{*}{\multicolumn{2}{|c|}{$\begin{array}{l}\text { Reduksi Kebisingan } \\
\text { (Rata-rata) }\end{array}$}} & \multicolumn{4}{|c|}{ Volume instrument mitigasi $\left(\mathrm{m}^{3}\right)$} \\
\hline & \multirow[t]{2}{*}{ NRV } & \multirow[t]{2}{*}{ NRT } & & & $\begin{array}{l}\text { Vegetasi/ } \\
\text { Gundukan }\end{array}$ & Beton / Bata & Area & Total \\
\hline & & & ER (\%) & 0.00 & $89.7 \%$ & $10.3 \%$ & & $100 \%$ \\
\hline \multirow{3}{*}{$\mathrm{T} 2$} & \multirow{3}{*}{13.87} & \multirow{3}{*}{54.18} & NRV (dBA) & 5.69 & \multirow{2}{*}{120.58} & \multirow{2}{*}{10.58} & \multirow[b]{2}{*}{-} & \multirow[b]{2}{*}{131.16} \\
\hline & & & NRT (dBA) & 5.45 & & & & \\
\hline & & & ER (\%) & 0.3 & $91.9 \%$ & $8.1 \%$ & & $100 \%$ \\
\hline \multirow{3}{*}{$\mathrm{T} 3$} & \multirow{3}{*}{7.86} & \multirow{3}{*}{51.62} & NRV (dBA) & 8.19 & \multirow{2}{*}{108.52} & \multirow{2}{*}{3.23} & \multirow{2}{*}{-} & \multirow{2}{*}{111.75} \\
\hline & & & NRT (dBA) & 9.63 & & & & \\
\hline & & & ER (\%) & -5.4 & $97.1 \%$ & $2.9 \%$ & & $100 \%$ \\
\hline \multirow{3}{*}{$\mathrm{T} 4$} & \multirow{3}{*}{45.96} & \multirow{3}{*}{90.34} & NRV (dBA) & 11.61 & \multirow{2}{*}{940.40} & \multirow{2}{*}{180.50} & \multirow{2}{*}{-} & \multirow{2}{*}{1120.90} \\
\hline & & & NRT (dBA) & 10.54 & & & & \\
\hline & & & ER (\%) & 1.3 & $83.9 \%$ & $16.1 \%$ & & $100 \%$ \\
\hline \multirow{3}{*}{ T5 } & \multirow{3}{*}{12.05} & \multirow{3}{*}{54.06} & NRV (dBA) & 5.48 & \multirow{2}{*}{461.11} & \multirow{2}{*}{13.53} & \multirow{2}{*}{1744} & \multirow{2}{*}{2218.64} \\
\hline & & & NRT (dBA) & 10.43 & & & & \\
\hline & & & ER (\%) & -6.2 & $20.8 \%$ & $0.6 \%$ & $78.6 \%$ & $100 \%$ \\
\hline
\end{tabular}

Sumber: Hasil Analisis, 2019

Hasil pengukuran reduksi kebisingan pada area vegetasi yang efektif terdapat pada titik ukur T1 dimana jumlah volume vegetasi $222.34 \mathrm{~m}^{3}$ mampu mereduksi kebisingan sebesar 11.61 dBA pada jarak ukur $15.64 \mathrm{~m}$ dan pada titik ukur T4 dengan jumlah volume vegetasi $940.40 \mathrm{~m}^{3}$ yang mampu mereduksi kebisingan sebesar $11.61 \mathrm{dBA}$ pada jarak ukur $45.96 \mathrm{~m}$. Besarnya efektifitas reduksi pada titik ukur T4 dipengaruhi oleh banyaknya jumlah serta jenis instrument mitigasi yang terdapat pada daerah ukur seperti pohon, taman, tugu, sculpture/patung, dan jarak ukur yang besar (lihat gambar 5). Selain pengaruh jarak, terdapatnya barrier berupa tembok atau pagar beton yang dibangun disekitar sumber suara dapat memantulkan sebagian bunyi sehingga yang sampai dititk pengukuran lebih kecil dibandingkan dengan titik lain meskipun dilihat dari jaraknya berdekatan dengan sumber kebisingan (Sasmita, Elystia, dan Asmura 2016). Penempatan barrier cukup efektif untuk mereduksi kebisingan, barrier dapat berupa dinding massif, pagar, gundukan tanah, tanaman pagar dan bangunan lain yang ditempatkan diantara sumber suara dan penerima (Widagdo, 1995).

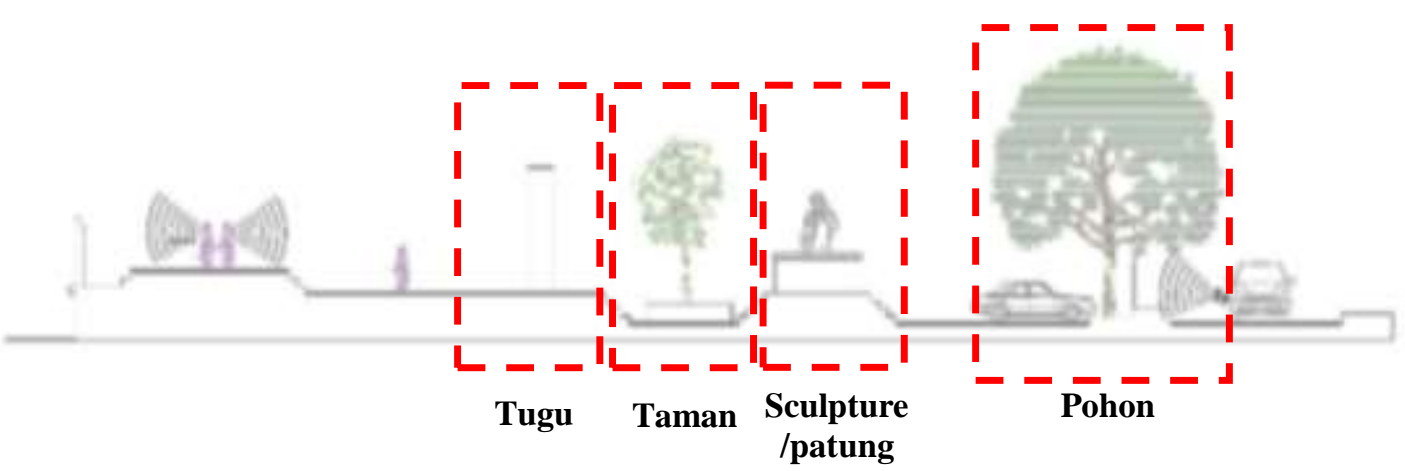

Gambar 5. Instrument Mitigasi Kebisingan Titik T4 Pelataran Pantai Loasi Sumber: Hasil Analisis, 2019 


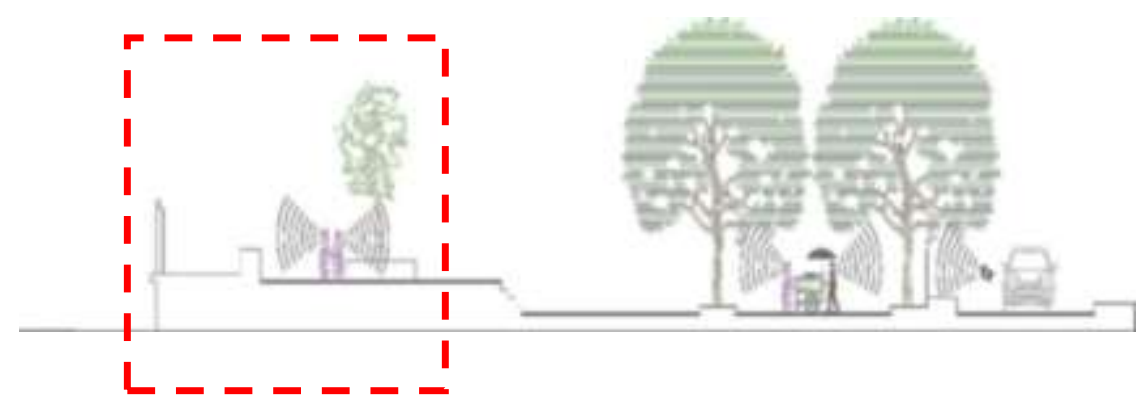

(a) Reduksi kebisingan ruang terbuka di titik ukur T5 Pelataran Pantai Losari

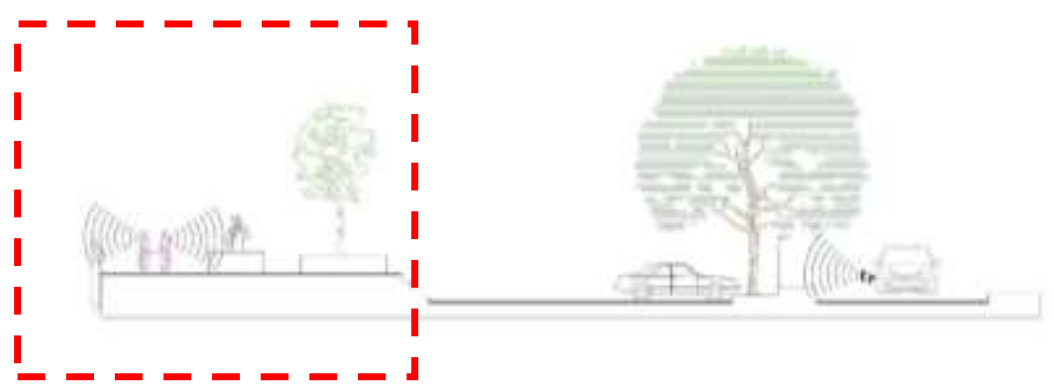

(b) Reduksi kebisingan ruang terbuka di titik ukur T1 Pelataran Pantai Losari

Gambar 6. Reduksi kebisingan titik T5 dan T1 Pelataran Pantai Losari Sumber: Hasil Analisis, 2019

Sebaliknya pada titik ukur T5 besarnya instrument mitigasi berupa area perdagangan yang berada pada daerah perlindungan vegetasi kurang mampu mereduksi kebisingan yang timbul dari aktivitas lalu lintas yang disertai dengan aktivitas perdagangan (gambar 6a). Vegetasi pada daerah terbuka lebih memberikan reduksi kebisingan yang lebih besar, hal ini juga terjadi pada titik ukur $\mathrm{T} 1$, instrumen mitgasi seperti pohon dan beton/bata lebih berperan besar dalam menurunkan nilai reduksi kebisingan pada ruang terbuka (Gambar $6 b$ ).

\section{KESIMPULAN}

Penelitian kebisingan Pelataran Pantai Losari menunjukkan bahwa rata-rata tingkat kebisingan dari aktivitas lalu lintas pada siang-malam hari sebesar 68,01 - 74,97 dB (A), dan tingkat kebisingan campuran dari aktivitas pengunjung serta aktivitas lalu lintas sebesar 68,02 73,86 dB(A). Meskipun sumber asal suara kebisingan yang terdapat pada Pelataran Pantai Losari dapat berpotensi menggangu kesehatan namun daya tarik kawasan Pantai Losari sebagai Landmark kota Makassar mempunyai nilai tersendiri bagi para pengunjungnya.

Instrument mitigasi yang berfungsi dengan baik dalam mereduksi kebisingan lalu lintas berada pada kawasan Pelataran bahari/pantai losari, hal ini dipengaruhi oleh banyaknya jenis dan jumlah instrument mitigasi yang terdapat pada daerah ukur seperti pohon, taman, tugu, sculpture/patung, disertai dengan jarak ukur yang besar. Selain itu instrument mitigasi berupa vegetasi dan sculpture/patung juga berfungsi secara efektif dalam mereduksi kebisingan dari aktivitas pengunjung pada titik ukur gerbang Tanjung dan Pelataran Mandar Toraja. 
Pantai Losari memiliki citra dan daya tarik khusus bagi masyarakat sekitar ataupun para wisatawan. Agar keberadaannya mampu memenuhi kenyamanan masyarakat maka sepatunyalah untuk dibenahi utamanya kebutuhan ruang hijau tidak hanya di tempatkan sepanjang bahu jalan tapi juga dalam kawasan Pelataran Pantai Losari. Kehadiran ruang hijau selain mengurangi tingkat kebisingan juga mampu mereduksi panas. Untuk penelitian selanjutnya sebaiknya membuat simulasi desain instrument mitigasi yang dapat mereduksi kebisingan, baik berupa tanaman ataupun penghalang lainnya.

Penelitian ini tidak dapat terlaksana tanpa bantuan dari berbagai pihak, untuk itu tim peneliti mengucapkan terimakasih kepada Kemenristek DIKTI selaku pemberi hibah dana penelitian dan kepada seluruh masyarakat pengunjung Pelataran Pantai Losari atas kerjasamanya.

\section{DAFTAR REFERENSI}

Departemen Pekerjaan Umum. 2005. "Mitigasi Dampak Kebisingan Akibat Lalu Lintas Jalan, Pedoman Konstruksi dan Bangunan." Pd T-16-2005-B.

Hakim, Rustam. 2012. Komponen Perancangan Arsitektur Lansekap. Jakarta: Bumi Aksara.

Juniardi. 2014. "Analisis Tingkat Kebisingan Lalu Lintas dan Penentuan Daerah Aman terhadap Gangguan Kebisingan (Jl. Soekarno-Hatta).” Jurnal teknik sipil UBL 5 (2).

Keputusan Menteri Negara Lingkungan Hidup. 1996. "Baku Mutu Tingkat Kebisingan.” Kep48/MENLH/11/1996.

Mansyur, Muchtaruddin. 2003. "Dampak Kebisingan Terhadap Kesehatan.” Yogyakarta.

Nyayu, L.S, dan H.S Budi. 2012. "Pemodelan Kebisingan Lalu Lintas di Jalan Terusan Kopo Bandung." Jurnal Teknik Sipil 8 (2): 76-141.

Sangkertadi. 2006. Fisika Bangunan untuk Mahasiswa dan Praktisi Teknik Arsitektur. Bogor: Wirausaha Muda.

Sasmita, Aryo, Shinta Elystia, dan Jecky Asmura. 2016. "Evaluasi Tingkat Kebisingan Sebagai Upaya Pengelolaan Kesehatan dan Keselamatan Kerja (K3) Di Unit Pltd/G Teluk Lembu Pt Pln Pekanbaru dengan Metode Niosh." urnal Sains dan Teknologi 15 (2): 34-42.

Susanto, B, dan ES Agata. 2011. "Potensi Material Lantai Halaman dalam Mereduksi Kebisingan Lalu Lintas." In Seminar Nasional-1 BMPTTSSI-KoNTekS 5. Medan: Universitas Sumatera Utara.

Widagdo, S. 1998. "Studi tentang Reduksi Kebisingan Menggunakan Vegetasi dan Kualitas Visual Lanskap Jalan Tol Jagorawi." Program Pasca Sarjana Institut Pertanian Bogor.

Zhang, M, dan J Kang. 2007. "Towards the evaluation, description and creation of soundscapes in urban open space.” Environment and Planing B: Planning and Design 34 (1): 68-86. 